\title{
わが国における住民参加型道路美化活動の現状と評価
}

\section{An Evaluation of Citizen Participation-type Road Beautification Activities in Japan}

\author{
亀野辰三* 熊野 稔** 岩立忠夫*** \\ Tatsumi KAMENO, Minoru KUMANO, Tadao IWATATE
}

\begin{abstract}
摘要：本研究は，わが国における住民参加型道路美化活動を対象として，これまでほとんど言及され ていない道路美化活動による効果とその評価を明らかにすることを目的としている。そのために, 2000 年の秋に全国の都道府県と市町村を対象にアンヶート調査を行った。その結果, 1) 住民参加 型道路美化活動に対する行政側の総合評価はかなり高い。2）住民参加型を実施すると「道路脇の美 化向上効果」はみられるが，「道路利用者のマナー向上効果」はあまり期待できない。3）因子分析 の結果, 行政側は住民参加型の効果を「地域自体のイメージ向上」と「道路利用者のマナー向上」の ニつの因子で捉えている，等が明らかになった。
\end{abstract}

\section{1. 研究の背景と目的}

近年, 道路や公園等の公共施設の美化活動にも住民参加が各地 で見られるようになっている。本研究で取り上げた道路の美化活 動においても,「街路樹愛護会」をはじめとする地域住民による 道路美化団体が結成されており,これまで日本各地で多くの実績 を積み重ねてきている。また，最近では「アダプト・プログラム」 (以下, AP) と呼ばれる契約型公共空間美化システムを導入する 自治体が增えている。APは, 行政側にとっては維持管理費の低 减が期待でき, 住民サイドによっても, 参加者同士の交流を通じ て健全な地域コミュニティの育成等に多大な効果があるとされて おり, 今後のまちづくりにおいて, 新しい可能性を秘めた環境パー トナーシップシステムとしても注目されている。しかしながら, すでに AP 導入後数年が経過し，これまでの先進自治体の取り組 みを通じて, AP を実施する上で幾つかの問題点も報告されてお $り^{1)}$, それらのうち, 既存の地域住民組織である自治会・町内会 やボランティア活動等との関係, あるいは, AP の効果とその評 価などの諸点が重要な検討課題となっている。

このような状況の中, 道路を含む公共施設を対象とした住民参 加型美化活動を扱った既往の研究をみると，公園を扱ったものが 大半を占めていることに気づく。これらには, 児玉ら (1999) ${ }^{2)}$ による行政と愛護会の双方へのアンケート調査により, 愛護会によ る街区公園の維持管理の実態を分析した研究や，岩村ら (2001) ${ }^{37}$ による公園管理会を対象として地域住民による公園管理の活動実 態と問題の所在を分析し, 公園における花壇の存在の重要性を指 摘した研究があり, 今後の維持管理の方向性に有益な示唆が与え られたが，いずれあ既存の住民組織を対象としており，活動によ る効果や評価には言及していない。また, 公園以外では, 市坪ら $(1997)^{4)}$ は, 全国の河川事業における住民活動の実態の把握之評 価を分析し, 住民と行政とのパートナーシップ構築の重要性を指 摘するなど貴重な示唆を含んでいるが, 清掃作業が対象外之なっ ていることから，河川の美化活動の評価には触れられていない。

一方, 緑化・清掃活動自体を対象とした研究においては, 田中 ら (1999) ${ }^{5)}$ は, 市民団体による緑化活動の実態を分析し, 活動 に対する評価から市民団体と行政及び行政関連諸団体との連携の 必要性を指摘している。また, 街区公園の再生を図るために住民 意識調査の結果から清掃活動の要因分析を行った嶋田ら (1998) ${ }^{6)}$ は，創発性と言うシステム論的な概念を用いて創発条件の考察を
試みている。しかし上記いずれの研究も, 道路以外を対象として おり，全国べースでの道路美化の実態把握や活動による効果に言 及した研究はまだ見あたらない。

そこで本研究は, 住民参加型道路美化活動による効果を検証す ることで，今後のわが国の道路美化活動に対し有用な情報を提供 することを目的としている。そのために，まず，全国の地方自治 体を対象にしてアンケート調查を行い，道路美化活動の実態を把 握することにした。次に, これらの調査結果に基づき, 特に, 道 路美化活動による効果とそれらに対する自治体の評価に焦点を当 て, 効果の内容や効果の重要度を検討する。最後に, 因子分析を 用いて行政側の評価構造を分析し，さらに類型化することにより， 住民参加型美化活動実施自治体のポジションを分析する。

\section{2. 全国自治体調查について}

\section{(1) 調查の対象}

わが国では，道路の維持管理は道路管理者が行っていること， 道路美化に関する全国べースでの正確な美化活動の実態を把握す る必要があること等から, 本研究では, 道路管理者を調查対象者 とした。具体的には，1)都道府県が管理する道路における住民参 加型美化活動（以下，住民参加型と略すこともある）の実態調查 （以下，都道府県調査）と，政令指定都市が管理する道路におけ る住民参加型の実態調査（以下，政令指定都市調査), 及び，2） 市町村が管理する道路における住民参加型の実態調査（以下，市 町村調査）の二つに大別して調査を行うことにした。

\section{(2) 調查の内容}

都道府県調查及び政令指定都市調查は, 2000 年 8 月末に 47 都 道府県と 12 政令指定都市の計 59 自治体を対象に調査票を郵送し, 46 都道府県之 11 政令指定都市の計 57 自治体（回収率 =97\%） から回答が得られた。また，市町村調査については，都道府県調 査の際に, 各都道府県において住民参加型で道路の美化活動を実 施している市町村名の調査も併せて依頼し, その結果, 何らかの 形で計 98 市町村（27 都道府県）が住民参加型美化活動を実施し ていることが分かり，これらの自治体を対象に郵送調查を 2000 年 11 月末に行い, 85 市町村（回収率=87\%）から回答が得られ た。

都道府県及び政令指定都市調查では, 住民参加型の対象を, (1) 街路樹のみの美化活動（以下，街路樹のみ)，(2)街路樹を含まな

*国立大分工業高等専門学校土木工学科 **国立徳山工業高等専門学校土木建築工学科 ‥*栃木県土木部 
い歩道のみの美化活動（以下，歩道のみ)，(3)街路樹を含む歩道 の美化活動（以下，両方）の 3 つに分類して調査することにした。 一方, 市町村調查では, 上記に加えて, 参加団体の推進主体, 行 政の関与の内容, 活動による効果とそれらに対する行政側の評価 等を尋ねた。また, 回答責任者は課長職以上の管理職と限定する ことで, 回答結果の信頼性を確保することにした。

なお，前述した，「街路樹のみ」とは，落ち葉の清掃や下草刚 り等の活動をいい,「歩道のみ」とは, 歩道上のゴミ・空き缶拾 い，花壇づくりや草花の手入れ等をいい，「両方」とは，以上の すべてを行う活動を指している。

\section{3 . 住民参加型道路美化活動の実施状況}

表一 1 で示したように, 都道府県調查で住民参加型を実施して いるのは, 35 都道府県 350 組織・団体（以下，団体），政令指定 都市調査では， 7 自治体 468 讨体，市町村調査では，計 54 自治 体 234 団体で，わが国全体では，計 96 自治体 1052 団体が住民参 加型を実施していることが明らかとなった。なお，同表からは， 都道府県では「街路樹のみ」の団体が $4 \%$ 上少数に止まっている のに比べ, 市町村ではそれが過半数(55\%)を占めるなどの特徴が 読みとれる。内訳を対象別にみても，「街路樹のみ」は全体の 5 $6 \%$ を占めており，「両方」を加味すると，わが国では 8 割程度 の団体は街路樹の美化活動に携わっているのではないかと思われ る。

以上のうち, AP を導入しているのは各調査時点において, 表一

表 -1 実施自治体と参加団体の状況

(上段:自治体数、下段:参加団体数と構成比)

\begin{tabular}{|c|c|c|c|c|}
\hline & & 動の 対 & & \\
\hline & 街路樹のみ & 歩道のみ & 両方 & \\
\hline
\end{tabular}

\begin{tabular}{c|c|c|c|r}
\hline \hline \multirow{2}{*}{ 都道府県 } & 6 & 22 & 18 & $35(6)$ \\
\cline { 2 - 5 } & $13(4 \%)$ & $169(48 \%)$ & $168(48 \%)$ & $350(9)$ \\
\hline \multirow{2}{*}{ 政令指定都市 } & 2 & 4 & 2 & $7(0)$ \\
\hline \multirow{2}{*}{ 市 町 村 } & $446(75 \%)$ & $9(2 \%)$ & $13(3 \%)$ & $468(0)$ \\
\hline \multirow{2}{*}{ 合 計 } & 21 & 17 & 17 & $54(7)$ \\
\cline { 2 - 5 } & $128(55 \%)$ & $38(16 \%)$ & $68(29 \%)$ & $234(9)$ \\
\cline { 2 - 5 } & $587(56 \%)$ & $216(20 \%)$ & $249(24 \%)$ & $1052(18)$ \\
\hline
\end{tabular}

注1)合計隔の上段の数字は実施自治体の数である。

注2)合計欄の（）内はAP実施数を示す。

表ー2 アダプト・プログラム導入自治体

\begin{tabular}{|c|c|c|c|c|}
\hline 管理者 & 治体 & $\mathrm{P}$ の名称 & 発足年 & 活動 \\
\hline \multirow{7}{*}{$\begin{aligned} & \text { 都 } \\
& \text { す道 } \\
& \text { る椨 } \\
& \text { 道県 } \\
& \text { 路管 } \\
& \text { 理 }\end{aligned}$} & 旦 & 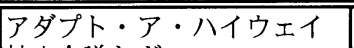 & 1年 & 渞 6 \\
\hline & 目 & & & \\
\hline & 三重県 & ふれあいの道里親事業 & 平成11年 & 両方 \\
\hline & 香川県 & 香川さわやかロード & 平成12年 & 歩道のみ \\
\hline & 広島県 & 広島県道路里親制度 & 平成12年 & 両方 \\
\hline & 大阪府 & アダプトロードたかはま & 平成 12 年 & 両方 \\
\hline & 神奈川県 & チポー & & \\
\hline \multirow{7}{*}{$\begin{array}{r}\text { 市 } \\
\text { す町 } \\
\text { る村 } \\
\text { 道が } \\
\text { 路管 } \\
\text { 理 }\end{array}$} & $\begin{array}{l}\text { (蜨启川 } \\
\text { 島田市 }\end{array}$ & | 谷口美里会 & 平成08年 & 両方 \\
\hline & 田原町 & （個人を対象） & 平成09年 & 街路樹の \\
\hline & 善通寺市 & アダプションプログラム & 平成11年 & 歩道のみ \\
\hline & 長門市 & みすずいいことシステム & 平成 12 年 & 歩道のみ \\
\hline & 半田市 & はんだクリーンボランティ円 & 平成 12 年 & 歩道のみ \\
\hline & 宇都宮市 & (個人を対象) & 平成 12 年 & 街路樹のみ \\
\hline & 利賀村 & 阿別当シルバー花の会 & 平成 12 年 & 歩道のみ \\
\hline
\end{tabular}

2 に示すように, 都道府県調査では徳島県, 広島県など 6 自治体 9 団体であり, 市町村調查では, 善通寺市, 半田市など 7 自治体 9 団体であったが，政令指定都市調査では AP の該当はなかった。 なお, 本調査で見る限り, わが国最初の $\mathrm{AP}$ は平成 8 年に導入し た島田市と考えられる。

\section{4 。道路美化活動に対する自治体の評価}

\section{(1) 活動による効果とその評価}

住民参加型道路美化活動の実施により，住民グループや地域社 会によ゙のような効果が発生するのかに関しては, わが国では, 竹 内 $(2000)^{7)}$ が AP の効果について言及している外は, 研究蓄積 がそしい。そこで，ここでは米・オクラホマ州が実施した $\mathrm{AAH}$ (Adopt-A-Highway program) に関する全米調査報告書 ${ }^{8)}$ を参 考にして表一 3 の左闌に示す 8 つ効果項目を設定した。

アンケートでは, 行政担当者に上記の 8 項目を提示し, 各効果 項目に対して, 大変効果あり〜効果あり〜あまり効果なし〜全く 効果なし，の 4 段階の選択記入を求めた。そして各効果項目に対 する 4 段階の評価にそれぞれ， $+3,+1,-1,-3$ の評点を 与え数值化してみた。なお, 有効回答数は 48 自治体である。

全体的に, すべての効果項目がプラス值となっており, とりわ け, [道路脇の美観向上](1.75) は最も高い評価点を得ている。次 いで，[地域のイメージ向上](1.50)，[地域コミュニティの育成］ (1.25), [参加者同士の交流](1.21), [維持管理費の低減](1.04) と いう順であり，これらの項目は効果があると評価しているようで ある。一方, [道路利用者のマナー向上](0.38), [ゴミのポイ捨て 防止](0.54), [地域に貢献する人材育成](0.75)の 3 項目に関して は，期待した効果は得られなかったと判断しているのではないか と思われる。

これらを美化活動の対象別でみると,「街路樹のみ］では, [道 路脇の美観向上］（1.44）, [地域のイメージ向上](1.33), [維持管 理費の低減](1.22), [地域コミュニティの育成](1.22), 等の項目 が比較的高い評価点を与えられているが， [道路利用者のマナー 向上] (0.00) と[ ゴミのポイ捨て防止](0.00)の 2 項目は, あまり 効果がなかったことを示している。

「歩道のみ」では, [道路脇の美観向上](1.71), [地域のイメ一 ジ向上](1.47)が評価点 1.0 以上を示し，他の項目はすべて 1.0 以 下の評価点であった。「両方」では, [道路脇の美観向上](2.23), [参加者同士の交流](1.77), [地域コミュニティの育成](1.77), [地域のイメージ向上](1.77)が比較的高い評価点を与えられてい るなど，すべての項目が 1.0 以上の評価点を示している。

以上は, 各々の評価項目に対する評価であり，これだけでは行 政側が住民参加型道路美化活動にどのような効果を期待している か，すなわち，行政側にとっての効果の重要度の順位が不明なの で, 効果項目を重要順に 3 つ挙げてもらい, これらにも各々, + $3,+2,+1$ の評点を与え, 数值化してみた。その結果, 最も

\section{表 -3 活動実施後の効果（評価点）}

\begin{tabular}{c|l|ccc|c}
\hline 順 & \multicolumn{1}{|c|}{ 効果項目 } & $\begin{array}{c}\text { 街路樹 } \\
\mathrm{n}=18\end{array}$ & $\begin{array}{c}\text { 歩道 } \\
\mathrm{n}=17\end{array}$ & $\begin{array}{c}\text { 両方 } \\
\mathrm{n}=13\end{array}$ & $\begin{array}{c}\text { 全体 } \\
\mathrm{n}=48\end{array}$ \\
\hline \hline 1 & 道路脇の美観向上 & 1.44 & 1.71 & 2.23 & 1.75 \\
2 & 地域のイメージ向上 & 1.33 & 1.47 & 1.77 & 1.50 \\
3 & 地域コミュニティの育成 & 1.22 & 0.88 & 1.77 & 1.25 \\
4 & 参加者同士の交流 & 1.11 & 0.88 & 1.77 & 1.21 \\
5 & 維持管理費の低隇 & 1.22 & 0.53 & 1.46 & 1.04 \\
6 & 地域に貢献する人材育成 & 0.67 & 0.41 & 1.31 & 0.75 \\
7 & ゴミのポイ搭て防止 & 0.00 & 0.65 & 1.15 & 0.54 \\
8 & 道路利用者のマナー向上 & 0.00 & 0.29 & 1.00 & 0.38 \\
\hline
\end{tabular}


重要な効果と判断しているのは, [道路脇の美観向上](96)点で, 以下, [参加者同士の交流] (46 点), [維持管理費の低減](42 点), [地域コミュニティの育成](40点), [地域のイメージ向上](32点), という順であった。[道路脇の美観向上]，すなわち，行政側は住 民参加型により，道路をきれいにする効果を期待していることが 分かる。一方, [道路利用者のマナー向上]( 7 点), [ゴミのポイ 捨て防止](13 点), [地域に貢献する人材育成](13 点) の三項目 には，あまり効果を期待していないことが示された。

\section{（2）住民参加型美化活動実施後の総合評価}

住民参加型美化活動を実施しての総合評価を伺ったところ, [良かった](35 自治体)，[大変良加た](11自治体)，[あまり良 くなかった]( 2 自治体)という順であり，[良くなかった]と回答 した自治体はなかった。アンケートに対する行政側の回答である 点を考慮しても，住民参加型に対して行政側はかなり高い評価を していることが分かる。これらを前述の数值化の方法で総合評価 点を算出し, 対象別にみると, 「街路樹のみ」(1.11), 「歩道のみ」 (1.24)，「両方」(1.92) となり，街路樹と歩道の両方を対象とした 住民参加型に対する総合評価が他の活動対象に比べ，かなり高い ことが分かる。住民参加型美化活動では, 落ち葉の清掃作業だけ ではなく, 花壇づくり等の緑化作業も併せて行うことの必要性を 示唆している。

\section{（3）総合評価による従来型と AP の比較}

ここで, 従来から行われている既存の住民組織等による美化活 動（以下, 従来型 $\left.{ }^{9}\right)$ ） と AP の評価を比較するために，実施団体 を別々に分離し総合評価の平均值を求めてみたところ, 前者は 1.44 (サンプル数 $\mathrm{N}=41$ ), 後者は $1.00($ 同 $\mathrm{N}=7$ ) となった。各々 のサンプル数がかなり異なるために両者の平均值の差を検定した ところ, 有意水準 $5 \%$ で両者の平均值に有意差は認められなかっ た $\left(\mathrm{F}=2.05<\mathrm{F}_{0.05}=2.90\right)$ 。つまり, 従来型と $\mathrm{AP}$ では, 本調査の 結果で見る限り, 総合評価において有意な差があるとはいえない ことが示された。

\section{5. 効果の分析と類型化}

\section{(1) 評価構造の分析}

前章で述べた各効果項目には互いに強い相関も見られる項目も あり, 効果項目の集約を行う必要があることから，ここでは因子 分析（主因子法, バリマックス回転）を用いて評価構造の分析を 行った。はじめに，有効回答のあった 48 自治体のデー夕を用い て因子分析を行ったところ，表一 4 に示すように 2 つの因子（固 有値 1.0 以上）が抽出され，第 1 因子に寄与している効果項目は, [地域に貢献する人材育成］を筆頭に，[地域コミュニティの育成］, [地域のイメージ向上], [参加者同士の交流]で, これらは「地域 自体のイメージ向上効果」(以下，イメージ向上効果）の因子で あると解釈した。

一方, 第 2 因子は, [ゴミのポイ捨て防止］と［道路利用者の マナー向上）が強く寄与していることから, 「道路利用者のマナー 向上効果」(以下，マナー向上効果）の因子と考えられる。これ らのことから, 行政担当者は住民参加型の効果について,「イメー ジ向上効果」と「マナー向上効果」の 2 つの側面に期待して評価 を行ったと推定される。

また，第 1 因子と第 2 因子の重みは寄与率の大きさから判断し て, 第 1 因子は第 2 因子の 2 倍程度であることが分かる。つまり, 行政側は住民参加型の道路美化活動に対して, 利用者のマナー向 上効果よりも, 地域のイメージアップ等に代表される地域自体の イメージ向上効果を，より期待しているのではないかと考えられ る。

（2）活動実施自治体のポジショニング

次に，住民参加型美化活動を実施している自治体の課題を探る
表 -4 因子負荷量及び累積寄与率

\begin{tabular}{|c|c|c|}
\hline 効果項目 & 第 1 因子 & 第 2 因子 \\
\hline (1) 参加者同士の交流 & 0.650 & 0.067 \\
\hline (2) 維持管理費の低滅 & 0.035 & 0.132 \\
\hline (3) 道路脇の美観向上 & 0.174 & 0.132 \\
\hline (4) 地域コミュニティの育成 & 0.728 & 0.067 \\
\hline (5) ゴミのポイ捨て防止 & 0.023 & 0.960 \\
\hline (6) 地域に貢献する人材育成 & 1.076 & 0.141 \\
\hline (7) 地域のイメージ向上 & 0.676 & 0.036 \\
\hline (8) 道路利用者のマナー向上 & 0.135 & 0.837 \\
\hline 固 有 值 & 3.262 & 1.538 \\
\hline 寄与率（\%） & 40.8 & 19.2 \\
\hline 累積奇与率（\%) & 40.8 & 60.0 \\
\hline
\end{tabular}

ために, 活動実施自治体のポジショニングを試みた。ここでは上 記の因子分析で得られた因子得点を用いて各自治体の類型化を行 うことにした（図-1)。なお，図中の $1 \sim 48$ と以下の括弧内の 数字は活動実施自治体を示す番号である。

図- 1 と表 -5 によると, 右上の象限（ここでは I 類型と名付 ける。以下も同様である。）は，イメージ向上効果とマナー向上 効果の両方が高い, 換言すれば理想的な活動が行われているグルー プといえよう。ここには, 木更津市(44)・上田市(24)など 21 自 治体が含まれ，望ましい形で活動を行っていると思われる。II類 型は, イメージ向上効果は認められるがマナー向上効果が振るわ ないグループである。湯布院町(47)・松戸市(30)など 9 自治体が 該当する。III類型は, イメージ向上効果は高くないが，マナー向 上効果は認められるグループであり, 利賀村(26)・宇部市(22)な ど 13 自治体が属している。IV類型は, マナー向上効果もイメー ジ向上効果屯共に低い，つまり住民参加型美化活動の効果があま り上がっていないと思われるグループである。ここには, 小出町 (25)・宇都宮市(13)など 5 自治体が含まれている。

一方, AP 導入自治体のポジションは, 田原町 (1)のみが I 類 型に位置する以外は, 残り 7 自治体とも正類型ないしIV類型に含 まれることから, イメージ向上効果, すなわち参加者同土の交流 や地域のコミュニティ醸成に課題があることが示唆されており, 必ずしも APが上手く機能していないことが何える結果となった。

なお，表一 5 にポジション別の自治体名を示したが，I類型が 全体の 44\%を占め最も多く, 次いで， III類型（19\%)， II 類型 (27\%), IV 類型（10\%)の順之なっている。つまり，わが国にお いては住民参加型道路美化活動を実施している自治体の約半数近 くは, イメージ向上とマナー向上の両面において, 行政側は住民 参加型の効果が上がっていると評価しているのではないかと思わ

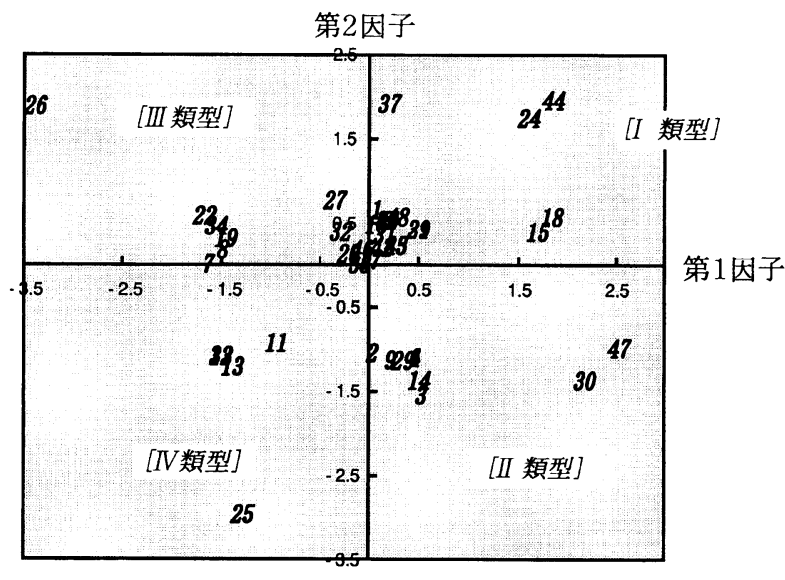

図一 1 実施自治体のポジション 
れる。

以上のように，因子得点を用いて実施自治体を類型化すること により, 自らのポジションを知ることができ, 住民参加型を実施 する際の課題の発見と今後の対策を講じる際の手がかりを与える ことができるのではないかと考えられる。

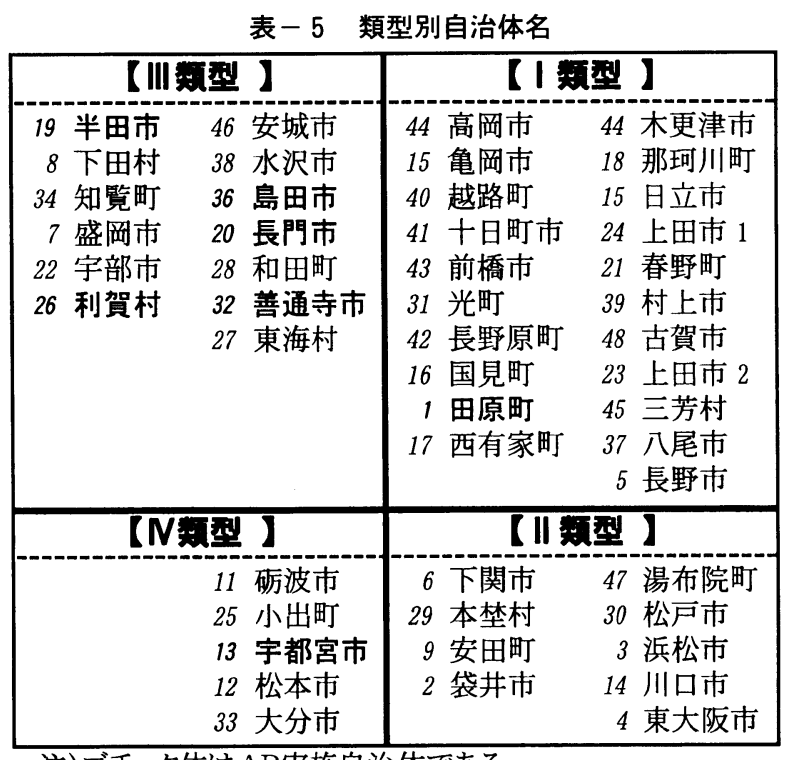

注)ゴチック体は $\mathrm{AP}$ 実施自治体である。

\section{6. 結論}

今回の調査は国管理の道路が含まれていないことなど, 必ずし あ客観的, 普遍的なむのにはなっていないことから, 本研究で得 られた知見の応用可能性については自ずと限界があるが，これら の限界を踏まえた上で, 本研究から得られた主要な結果を以下に 示すとともに, APの今後の課題を述べ，本研究の結論としたい。

(1)住民参加型に対する行政側の総合評価はかなり高く, 行政側 の評価であることを割り引いても，お打む効果はあると判断し
ているようである。効果の内容では, 行政側は, 活動実施により, 道路脇の美観向上効果や地域のイメージ向上効果があったと評価 しているが, 道路利用者のマナー向上効果やゴミのポイ捨て防止 効果には懐疑的であることが把握された。このことは, 住民参加 型は, 地域住民には一定の効果をむたらすが, 一方で, 地域住民 以外の道路利用者にはあまり効果がないことを示しており, 今後, 住民参加型美化活動の効果を高めるためには, 道路利用者のマナー を向上させる方策を具体的に検討する必要がある。

(2)住民参加型による各効果を集約するために因子分析を行った ところ, 行政側は「地域自体のイメージ向上効果」の因子と「道 路利用者のマナー向上効果」の二つの因子で評価していることが 明らかになった。また，その重みは前者が後者の 2 倍程度高い。 つまり，行政側は地域のイメージアップ等に代表される「地域自 体のイメージ向上効果」を住民参加型に期待しているのではない かと考えられる。

(3)住民参加型を実施している自治体を「地域自体のイメージ向 上効果」と「道路利用者のマナー向上効果」の 2 軸で類型化する ことにより, 自治体は自らのポジションを知ることが可能となり, 問題点の発見や今後の対応策の検討に手がかりを与える可能性が 示された。

なお, 本研究を通じて, 導入期における $\mathrm{AP}$ の評価も一部試み たが, 調查時点では, まだ市町村レベルで 7 自治体に導入されて いるに過ぎず, 従来型の美化活動と総合評価で有意な差は見出せ なかった。また，因子得点によるポジショニング分析の結果でも， $\mathrm{AP}$ 実施自治体の多くが「地域のイメージアップ」に課題がある ことが示唆されている。しかしながら, AP の効果を検証するに は, 屯う少し事例の積み重ねが必要と思われ, 今後は $\mathrm{AP}$ 導入自 治体への調查と並行して, 実際に活動に参加する住民にアンケー トを行い効果を検証するなど, 効果の評価には未だ多くの検討の 余地が残されている。

終わりになりましたが, 本研究を遂行するに当たり, 大分大学 工学部佐藤誠治教授からは数々の有益なご助言とご指導を賜りま した。ここに記してお礼申し上げます。

\section{補注及び参考文献}

1) 社団法人食品容器環境美化協会 (2000): 第 2 回アダプト・プログラム研究会報 告書

2 ）览玉陽子・嶋田喜昭・舟渡悦夫 (1999)： 公園愛護会による街区公園の維持管理 の実態について：土木計画学研究講演 集 No.22(1), 255-258

3 ) 岩村高治・横張真 (2001) : 神戸市に おける地域住民による公園管理の実態 とその展望：ランドスケープ研究 64(5), 671-674
4 ）市坪誠他（1997）：河川整備に対する 住民活動の評価に関する一考察：第 11 回環境情報科学論文集, 55-58

5 ) 田中他（1999）：東京都世田谷区にお ける市民団体による緑化活動の実態に 関する基礎的研究: 第 13 回環境情報 科学論文集, $79-84$

6 ）嶋田他（1998）：清掃活動の要因分析 からみた街区公園の創発性に関する研 究: 第 12 回環境情報科学論文集, 161166

7 ) 竹内尚之（2000）：住民参加型道路維
持管理システム「あいロード」につい て: 道路交通経済 2000-7, 18-23

8 ) Oklahoma Department of Transportation Beautification Office (1999): 1999 Adopt-A-Highway Survey United States and International

9 ) 従来型と AP との区別は, アンケート 調査の回答で，行政側が当該実施団体 を“アダプト・プログラム”と明記し ているのを AP とし，それ以外を従来 型とした。

Summary : This research has aimed to clarify the effect of the road beautification activity which has been hardly referred up to now and the evaluation for citizen participation-type road beautification activity in our country. In autumn of 2000, a survey was conducted, targeting prefectures, cities, towns and villages all over Japan. As a result, the following facts have come into light:

1) The overall evaluation on an administrative side to citizen participation-type road beautification activity is considerably high.

2) "Road user's effect of the manners improvement" cannot be so expected though "Effect of the fine sight improvement the road sideward" is seen when citizen participation-type is executed.

3) As a result of the factor analysis, an administrative side captures the effect of citizen participation-type by two factors of "Improvement of the image of the region" and "Manners improvement of the road user". 